\title{
An Analysis of the Factors Affecting Huck's Growth
}

\author{
Yanxia Sang \\ Basic English Department, Dezhou University, Dezhou City, Shandong Province, China \\ Email: dz_syx@126.com
}

\begin{abstract}
Huckleberry Finn is one of Mark Twain's outstanding masterpieces. Superficially, it tells a story about a 13 or 14 year old boy's adventures with Negro Jim on the Mississippi river. In fact, it reflects the growth process of Huck through adventures. His growth is embodied by his choice on independence, his change of attitude towards Jim, his moral growth, and the different social roles he plays. Huck's growth is influenced by the inner and outer factors. On the one hand, friendship, nature and society make up the outer environment for Huck's growth. They have great effect on the development of his growth. On the other hand, his own instinct and his sound heart finally decide the direction of his growth.
\end{abstract}

Index Terms - growth, the influence of Jim, nature and society, instinct, sound heart

\section{INTRODUCTION}

Mark Twain is a giant in American literature. He is a great realist and satirist in late 19th century. His delicate familiarity with children's psychology, his thorough understanding of Americans and American society, his great contribution to American English and his immense witty humor have won great respect and reputation among the people around the world.

Of all the works Mark Twain accomplished in his life, the Adventure of Huckleberry Finn is the most successful. This remarkable masterpiece brings the world prestige to him. It is the combination of simplicity and subtlety, directness and complexity that has given the novel its status as the American classic. Seemingly the novel is telling a story of a young boy and a runaway slave journeying on the Mississippi. However, it is of great moral passion. It deals with the virtue and depravity of man's heart, which can only be fully understood by adult readers.

While confronted with and dealing with the contradictions during the adventures, Huck is increasingly growing up. His growth is embodied in terms of the establishment of independent personality and moral progress. Growth of any adolescence will be influenced by outer and inner factors. Huck is no exception.

\section{THE FACTORS INFLUENCING HUCK'S GROWTH}

Huck's growth consists of the establishment of his independent personality, his moral growth and the different social roles he plays. During the process of Huck's growth, both the outer and inner factors play very important roles that are illustrated as the following.

\section{A. Negro Jim}

On the road of Huck's growth, his fellow Negro Jim plays a very important role. He is the guide of Huck's growth. That he can take on such a role is based on the following aspects.

Firstly, although Jim is not so clever and intelligent as Huck, he is sincere, trustworthy and honest, and he is always ready to help others. Such good qualities enable Jim to be a positive guide of Huck. He teaches Huck what a friend means and what loyalty is. Jim's sincerity is established in several ways. The most potent example is his joy at seeing Huck alive again after the fog separates them. Jim gets upset with Huck for tricking him into believing it was all a dream precisely because he had invested a great deal of emotional content into the adventure. It also starts to become obvious that Jim would be willing to sacrifice a great deal to make sure that Huck is safe. The problem at this juncture of the novel is that Huck does not reciprocate Jim's feelings about him. Huck is not yet willing to sacrifice part of his life to ensure Jim's safety and thus leads Jim from one adventure to another, be it on the wrecked steamboat or during the fog. This is important because it is Huck's loyalty to Jim that will be tested later. There is a distance between their ages, but they can get along well with each other. Jim appears at times as a substitute father for Huck. He takes care of Huck like both a father and a friend. In chapter 20, it is Huck's duty to be on watch, but he was pretty sleepy, so Jim said he could stand the first half of it for Huck. In Huck's eyes, he is always "mighty good". (188)

Secondly Jim loves his family and he makes Huck find a family. When Jim discusses his family, Huck comments that he is surprised to find that Jim is almost as concerned about his family as a white person. This prevailing attitude, which often is invoked, to justify breaking up slave families, is an attitude that Huck is overcoming. Jim's touching story about his daughter Elizabeth, in which he hits her for not obeying him, is a powerful indication to Huck that Jim is 
in fact more concerned about his children than Huck's father ever was about him.

Thirdly, Jim has strong self-esteem. Slave as he is, he never looks down upon himself before Huck. He regards himself to be equal to everyone. Once the fog separates Huck and Jim, Jim was so worried about Huck. However, when Huck comes back safely, he fools poor Jim. Jim isn't subject to Huck because he is a slave. On the position of a friend, Jim tells Huck his feelings. Jim's self-esteem gains the return of Huck's respect.

Lastly, his spirit of revolt arouses Huck's sense of justice. Jim is an image of rebellion. He is not subject to the control of his owner. He wants to get the independence and liberate his family members. Although, from the perspective of white people, it is illegal and unacceptable for Jim to escape, his love for his family and his pursuit of freedom and happiness get Huck to know that black people are also human beings, and they are equal to white people.

The above aspects apply for Jim's role as a guide. He not only acts as a surrogate father to Huck, but also provides Huck with the opportunity for moral growth. His good qualities have a positive effect on Huck. As a child, Huck's moral ideology is not completely sound. He tends to be influenced by the surroundings around him. The corrupted society pains him. Jim as a guide on the road of Huck's growth can lead him to the right way. He expresses his parental feeling for Huck, and makes Huck find a family. Through his sincerity and his loyalty, Jim clears up the discrimination in Huck's mind step by step. Huck's sense of morality comes from Jim. They establish intimate relationship, sometimes like friends, sometimes like father and son. The establishment of such relationship is on the equal basis. Although Jim is uneducated, the good qualities enable him to be the guide of Huck. He is like a pilot on the journey of Huck's growth and makes Huck drive in the right direction. The reader is left to believe that Huck has truly found a father in Jim, and realizes that color is no barrier in love and friendship.

\section{B. Nature}

Nature is another positive factor influencing Huck's growth. It provides a pure environment for the growth of Huck. Floating on the raft down the Mississippi river, the life is quite different from that on the bank. Nature clarifies and purifies Huck's mind. There is no greed, deceit, hypocrisy and cruelty. The life on the river makes a clear contrast with the life on the bank. The raft is the symbol of freedom, and it takes Huck and Jim to freedom. The life on the raft represents harmony, tranquility, friendship and freedom. Huck and Jim get along well with nature. Compared with the tedious life in the civilized society, Huck thinks that "there wasn't home like a raft, after all. Other places do seem so cramped up and smothery, but a raft doesn't. You feel mighty free and easy and comfortable on a raft." (128)

The raft is the home of Huck. He feels warmth and responsibility. This is the free life he pursues. What's more significant is that, when confronted with the dangers together With Jim, he makes friends with Jim and knows the real meaning of friendship. In pure nature, there is no slavery, no discrimination. Huck and Jim are equal to each other. They should cooperate with each other to deal with the hardship. Nature is presented as a thought-provoking environment. Therefore the great pure nature clarifies Huck's conscience, which has been ill trained by the deceitful civilized world. The return to nature arouses his instincts of integrity. When Huck and Jim encounter any trouble on the shores, they retreat to the river. The river not only serves as a linkage of adventure, but also symbolizes the freedom, equality and brotherhood that Huck and Jim are seeking. The river is a quiet and peaceful place where Huck can revert to examine any predicament he might find himself in. On the river, Huck is as free as a bird out of a tiny cage. The floating on the river provides Huck with a healthy environment for his psychological development, and it records his trace of growth. River is his destination, and only on river can he breathe the fresh air and enjoy freedom. The endlessly flowing river symbolizes a life journey. It brings up Huck, and his thought elevates. He began to grow into an independent youth from a naughty child. The uncivilized nature endows Huck with instinct of pursuing freedom and justice. It also trains his sound heart. As a homeless child, nature is Huck's beloved home, and it is like a mother caring for Huck. In the family of nature, Huck's sound heart comes into being and his psychology develops healthily.

\section{Society}

If Jim and nature teach Huck how to be a man from a positive perspective, society "educates" Huck how to tell good and evil from the negative aspect. Huck is born into nature, but is morally influenced by society. From chapter 16 to chapter 30, each chapter brings in new characters and adventures, which highlight particular prejudices or follies of the characters. People's greed, deceit, hypocrisy and cruelty in the civilized society are thoroughly exposed in the eyes of Huck. The evil phenomena, such as humanity's cruelty, cowardice, deceit and injustice, form a strong contrast with the tranquil picture of the Mississippi river. The strong contrast impacts Huck's heart. On the river, it is a world of brotherhood, equality and freedom; on shores, what one can see are the frauds murder and other vices of human society. The bars and shackles of civilization shut him in and bound him hand and foot. During the adventures, Huck is thrown out into a very hypocritical hostile world. He witnesses the wholesale slaughter of the Granger fords and the cold-blooded shooting of old Boggs. The casual violence is all pervasive. Such violence makes for a mood of general apathy, of complete indifference. Boggs's death focuses the reader's attention on a much more serious aspect of the society. Boggs is shot to death in front of his daughter and with a crowd of people watching. The disrespect shown to Colonel Sherburne hardly justifies killing a man directly in front of his own daughter. The lust of money cannot be resisted in the civilized society. Miss Watson could not resist the eight hundred corrupting dollars offered her by the nigger trader for Negro Jim. The ling and the duke perform their monstrous frauds for money alone and finally betray Jim for forty dollars. The adventures force Huck to play different roles as he tries to assimilate himself into each new 
situation. One adventure after another, Huck is more and more mature. He has acquired a profound and bitter knowledge of human depravity. He rejects the society full of evils. Huck's pure eyes expose the decadence of the society.

He sets his face against the conventions of civilized morality. The society shows him the evil side, which brings Huck to challenge the conventions and establishes his own standard of justice. Meanwhile Huck learns how to survive in the deceitful and cruel society. The people in the society have gotten involved in the old conventions, which also influence Huck's growth. The civilized society continuously assimilates Huck's pure and natural heart. However, the influence of the society is negative, which enhances Huck's rejection to the civilized society and the old conventions. At last, he gives up the social morality, and chooses to trust his natural morality again.

\section{His Sound Heart or his Natural Instinct}

The most significant factor affecting the growth of Huck is his own sound heart. In a notebook entry, Twain referred to Huckleberry Finn as "a book of mine where a sound heart and a deformed conscience come into collision and conscience suffers defeat." The sound heart makes Huck able to gain access to truth and defeat the "conscience" ill-trained by the civilized society. The course that sound heart beats the "conscience" is the process of Huck's growth. His conscience is influenced by the social conventions. He undergoes various tests and is confronted with complex conflict. Step by step he is growing up.

Huck is uneducated, coarse, naughty and untamed, but meanwhile, he is upright, kind and realistic. The social conventions leave few traces on him. He chooses to stay with Jim because as a young boy he still lacks the prejudices of the older folks in his town. Therefore he has the thought of equality and sense of justice, and he is brave to reject the traditional conception. Naturally, his growth is not accomplished in one step, but develops gradually.

As a white boy, brought up in a countryside where slaveholding system is a matter of course. Huck is influenced by the public view of racial prejudice and discrimination. Like the rest of society that surrounds him, he always derides, teases and deceives the blacks. He does not see black people as equals and he refers to Jim as merely a piece of property. In the very beginning, Huck tricks on Jim and makes fun of Jim. He considers Jim inferior in status. When a snake bit Jim due to his prank, Huck did not express concerns for Jim's safety; he was more concerned with being caught. This opinion does not cease to exist until the time when the two of them meet again after the fog. The fog separates Huck and Jim. Jim is so worried about Huck and he seeks for Huck desperately on the raft. However, Huck hoaxes him into believing that he only had a dream. When Jim knows the truth, he criticizes Huck severely. Huck is educated by Jim's reaction, and he realizes that Jim is a man with strong self-esteem. He brings himself to make an apology to Jim. He humbles himself to a nigger, and is not "sorry for it afterwards, never". (89) This is the turning point of his attitude towards slaves, and it is also the first step that he gets away with conventions and prejudice. When the raft approaches the city of Cairo, Huck feels more and more upset. For Jim, Cairo symbolizes freedom; for Huck, the prison of moral conflict. Raising his deformed conscience to decision, Huck takes off in a canoe to go and give Jim up. However, when a passing raft comes alongside Huck's canoe, his sound heart triumphs and he saves Jim by lying. This is the second step for Huck to separate with the power of traditional conventions.

In chapter 31, Huck's contradictory thoughts come to climax, knowing Jim was sold by the "King", Huck is afraid of being known that he has once helped a nigger to get his freedom. He thinks that he has done a low-down thing. Then he writes to Miss Watson, reporting whereabouts of Jim. However, thinking about those days and nights he has spent with Jim and considering how kind Jim has been to him, Huck is caught in a dilemma. He recalls the raft journey, which is full of happiness and love. Huck is forced to finally decide between right and wrong concerning slavery, and as such must solidify his own morality. He finishes by deciding to follow his sound heart and free Jim. He studies the letter and holds his breath, and finally decides, "all right, then, I'll go to hell", (156) and tears up the paper. The fact that Huck is willing to sacrifice his own soul to hell for Jim's sake shows the tremendous amount of personal growth that Huck has undergone. In the earlier chapters Huck would never have considered making such a sacrifice. This scene indicates how his relationship with Jim has changed over the course of the journey downriver, from companion to respected friend to being the only family that Huck will acknowledge. Huck makes his decision after remembering all the times that Jim protected him and cared for him, something that no one else has ever done for Huck. Up until this point he has followed the authority of those around him, such as Pa, the Widow, Miss Watson, Judge Thatcher, the King, and the Duke. He breaks free of this authority the moment that he decides to free Jim. For the first time Huck is actually acting on his convictions and morals, rather than on his desires and wants. It is now that Huck accomplishes his decisive step. This moment is life-altering for Huck because it forces him to reflect everything that civilization has taught him; he makes the decision to free Jim based on his own experiences and not based on what he has been taught from books. Huck's decision to steal Jim symbolizes the victory of his sound heart over deformed conscience.

The raft journey towards freedom is Huck's growing process. During the process, Huck is tortured by the conflicts between the individual and the society, between the sound heart and the deformed conscience. As an individual, Huck pursues the freedom; he is not going to subject to the conventions and restrains. As for the issue of slavery, he sympathizes with Jim and he is brave to break the established law. Standing alone against the society is both challenging and painful. People have the tendency to be in the mainstream, following blindly what they are taught to believe in. However, child as Huck is, when his ideas conflict with the social conventions he dares to make his own decision. On the deeper level, the conflict between the individual and the society reflects the contradiction between 
sound heart and deformed conscience. From the time when Huck meets the fleeing Negro Jim, the friction has tortured him between his sound heart and the deformed conscience. He wrestles with his conscience. His "conscience" tells him that he is doing wrong and that he is to blame. He makes great efforts to persuade himself to follow social training, yet he succumbs to his sound heart. He is obviously maturing in his views, as evidenced by his belief that black and white people are not so different. He is also changing from a boy who lacks firm morals to a man with a commitment to values. Thus his commentary is no longer merely descriptive, but is becoming more and more evaluative as he goes along. It is becoming obvious that Huck will not be content to stand aside and let things slide past him, as the metaphor of gliding down the river suggests. Instead, Huck is about to take a stand and assert himself as an individual and a person. Thus his attitudes will eventually bear fruit in his actions, which is the final step in Huck's journey towards mature individuality. Through self-education, Huck gets a further and better understanding of the society and human beings.

\section{CONCLUSION}

The Adventures of Huckleberry Finn tells the story about the process of an adolescent's growth. Huck, like other adolescents, is confronted with various conflicts and puzzles. When he steps into the society, into adults' world, he witnesses the lust, deceit, violence and old conventions. In the complexity of good and evil, he sometimes feels at a loss, even loses his way to growth. Due to his innocence, he is apt to be influenced by the outer factors, such as people and the environment around him. Meanwhile, as an individual, he is very independent. He begins to have his own thinking. To think independently is the significant sign for one's growth and maturity. All the factors, outer or inner, influence Huck's growth; however, his sound heart, as the inner factor, plays the decisive role in his growth.

\section{REFERENCES}

[1] Beaver, Harold, ed. (1987). Unwin Critical Library, vol III. London: Allen \& UNWIN.

[2] Pizer, Donald, ed. (1987). The Cambridge Companion to American Realism and Naturalism. London: Cambridge University Press.

[3] Twain, Mark. (1985). The Adventures of Huckleberry Finn. England: Penguin Classics.

[4] Cunliffe, Marcus. (1986). The Literature of the United States. New York: Penguin Books Ltd.

[5] Eliot T. S. (1950). "Introduction," Adventures of Huckleberry Finn. New York: Chanticleer Press.

Yanxia Sang was born in Dezhou city, Shandong Province, China in 1976. She received her M.A. degree in linguistics from Shandong University, China in 2008.

She is currently a lecturer in Basic English Department, Dezhou University, Dezhou city, Shandong Province, China. Her research interests include English and American literature. 